\title{
Immunological Distribution of the Placental Lactogene and IGF-1 Receptor on Free-chorionic Villi of the Newborns Small for Gestational Age Placentae
}

\author{
Distribución Inmunológica del Lactógeno Placentario y los Receptores IGF-1 en Vellosidades \\ Coriónicas Libres de los Recién Nacidos Pequeños para la Edad Gestacional
}

"Ruth Prieto; **Fernando Matamala \& ***Mariana Rojas

PRIETO, R.; MATAMALA, F. \& ROJAS, M. Immunological distribution of the placental lactogene and IGF-1 receptor on freechorionic villi of the newborns small for Gestational Age placentae. Int. J. Morphol., 26(4):1029-1033, 2008.

SUMMARY: The aim of this study was observe differences in the immunological distribution of the placental lactogene and IGF-1 receptor on free-chorionic villi, between studied groups and to relate the neonatal diagnosis of PEG with morphometric and immunohystochemical characteristics of the placenta. A total of, twelve placentas from AEG newborn and twelve from PEG newborn were obtained from the Maternity Ward of Temuco, Chile. H\&E, Alcian blue and Masson's trichromic stains, as well as HematoxilynPAS. In the immunoperoxidase technique, were used: 1) placental lactogen (polyclonal, dilution 1:200, NCL-PLP, Novocastra) 2) Insuline1 like growth factor (monoclonal, dilution 1:200, NCL-GHR, Novocastra). Differences between PEG and AEG placentae in the immnunostaing for placental lactogen and IGF-1 receptor in the sincitial throphoblast were not observed.

KEY WORDS: IGF-1 receptor; Free-chorionic villi; Newborns; Gestational age.

\section{INTRODUCTION}

The placental chorionic villi elaborate hormones such as the growth hormone and placental lactogen, which determine the normal development of various fetal organs. In cases of pathological placentae, those factors would not normally be produced, generating some defects in the newborn, such as the low weight at birth (Belizan et al., 1999). The production of placental lactogen is related to the functional trophoblast, in other words, to the placental weight. The Insulin 1-Like Growth Factor (IGF-1), on the other hand, promotes the fetal growth during development before and after birth, at a time when the concentration of IGF-1 both in blood and the umbilical cord are correlated with the fetal size (Sadler, 2004; Carlson, 1999).

It has been reported that mothers of IUGR newborns have also presented, in general, a lower level of education (Frisbie et al., 1997), less prenatal care (Visscher et al., 2003), a lower weight increment during pregnancy (Newburn-Cook et al., 2002; Strauss \& Dietz, 1998), gestationally-induced arterial hypertension (Doctor et al., 2001) development of cardiovascular pathologies (Eriksson et al., 2001; Oren, 2003), arterial hypertension (Do Carmo Pinho Franco et al., 2003), inadequate lung functioning (Dezateux et al., 2004) and diabetes (Leger et al., 1997). Some ethnical differences have also been reported to exist (Alexander et al., 1999). The habit of smoking during pregnancy would also affect the placental function and hence the fetal growth (Vogt et al., 2004).

Fetal tissues expressed IGF-1 and its levels in serum are correlated with fetal growth. Mutations in the IGF-1 gene result in manifestation of IUGR, which extend after the birth (Carlson). It also plays a role in the nutrients division in the fetal-placental unit (Gluckman \& Harding, 1997). The factor IGF-1 is detected in fetal tissues from the ninth gestational week on. The importance of the IGF-1 on fetal growth is deduced from the association observed between low hormone concentrations and fetal risk seen in $57 \%$ of newborn with IUGR and a $13 \%$ perinatal mortality seem to be related to a deficit in placental lactogen secretion (Handwerger \& Freemark, 2000).

\footnotetext{
* Pediatric Department, Faculty of Medicine, Universidad de La Frontera, Temuco, Chile.

** Anatomy Department, Faculty of Medicine, Universidad de La Frontera, temuco, Chile.

${ }^{* * *}$ Anatomy and Developmental Biology Program, Faculty of Medicine, Universidad de Chile, Santiago, Chile.
} 
The objective was to recognize the differences in the immunological distribution of the placental lactogene and IGF-1 on free-chorionic villi, between SGA and AGA (Adequate for Gestational Age) placentae. And finally, to relate the neonatal diagnosis of SGA with morphometric and immunohystochemical characteristics of the placenta, by a score or placental factor.

\section{MATERIAL AND METHOD}

A total of 24 terminal placentae, from a single gestation, with no malformations, from cesarean operation and normal labour were used. Twelve from AGA newborn (control group) and twelve from SGA newborn (study group) were obtained from the Maternity Ward, Temuco, Chile. Placentae were rinsed with tap water and fixed in buffered $10 \%$ formalin. Histological and histochemical techniques such as H\&E, Alcian blue and Masson's trichromic stains, as well as Hematoxilyn-PAS (peryodic acid Schiff, McManus, 1948) and Diastase-PAS. In the immunoperoxidase technique, the following primary antibodies were used: 1) placental lactogen (polyclonal, dilution 1:200, NCL-PLP, Novocastra) to label cytoplasmic granules from the syncytial trophoblast; 2) Insuline-1 like growth factor (monoclonal, dilution 1:200, NCL-GHR, Novocastra).

For the positive control AGA newborn placentae cuts were used. And for the negative control, cuts adjacent to the ones treated with the primary antibody were used and were treated with the same technique, except that the primary antibody was replaced with non-immune mouse (Dako) serum. The following parameters were evaluated in transversal sections from the free-chorionic villi: cross section area, number of blood vessels and blood vessel area. Histological sections from placentae were analyzed at $1000 \mathrm{X}$ magnification, under a NIKON Eclipse E 400 light microscope equipped with a digital camera NIKON E 4500. The software Image Tool version 3.0 was used to perform this morphometric study. The statistical software GraphPad Prisma and the Student $t$ test were used. Results are presented as mean $\pm \operatorname{SEM}(\mathrm{xx} \pm \mathrm{SEM})$ and $p \leq 0.05$ was considered to be statistically significant.

\section{RESULTS}

In the SGA group, the immunostaining for the IGF-1 receptor was evidenced in some intermediate and stem chorionic villi, in both groups. Positive immunostaining was not observed in terminal chorionic villi. The labeling was detected in the apical region of the cytoplasm of the syncytial trophoblast as well as in the cytoplasm of 5 to 6 stromal cells per villi (Fig. 2b). Placental lactogen immunostaining was positive in the stem, intermediate and terminal chorionic villi. This was observed as granules in the cytoplasm of the syncytial trophoblast (Fig. 2c). Both the intensity of the stain and the thickness of the granules increase in the syncytial nodes and decrease and became negative in the syncytial vascular layer or alpha zone. Negative staining was observed in the cells from the cytotrophoblast, the nuclei from the syncytial trophoblast and the stroma of the villi. Morphology of the free chorionic villi from AGA newborns. Figures 1a show that a denser stroma is evidenced, the basal membranes are thinner than those from the SGA group (Fig. 2a). Immunostaining for the IGF-1 receptor is similar to that shown in the SGA group (Fig. 1b) and the placental lactogen is similar to what is observed in AGA placentae (Fig. 1c).

As a result from the analysis, a score or placental factor (Table I), was obtained in order to contribute to the assessment of the placental functioning, to be used in conjunction with clinical evaluation of the new born and the modern methods of perinatal monitoring.

Table I. Placental score.

\begin{tabular}{lcc}
\hline Placental weight $(\mathrm{g})$ & $\leq 342$ & 1 point \\
\hline Placental diameter $(\mathrm{cm})$ & $\leq 15$ & 1 point \\
Placental infarctions & Yes & 1 point \\
Free-villi major diameter $(\mu \mathrm{m})$ & $57 \pm 19.7$ & 1 point \\
Capillary loops & Yes & 1 point \\
Blood vessel dilatation in & Yes & 1 point \\
peripheral capillaries & & \\
Undifferentiated stroma with few & Yes & 1 point \\
colagen fibres & & \\
\hline Total & & 7 points \\
\hline
\end{tabular}

\section{DISCUSSION}

The inmunostaining between both groups was not significantly different, indicating that this would not be the only mechanism related to the placental weight. It must be kept in mind that the production of IGF-1 decreases with maternal undernourishment, excess of glucocorticoids and hepatic insufficiency (Sadler). The placental lactogen seems to intervene directly in the maternal metabolic adaptation to the gestation. In women, the hPL (human Placental Lactogen) acts in a coordinated manner with the somatotrope hormone, stimulating the production of maternal IGF-1 factor and modulates the intermediate metabolism, which favors the 

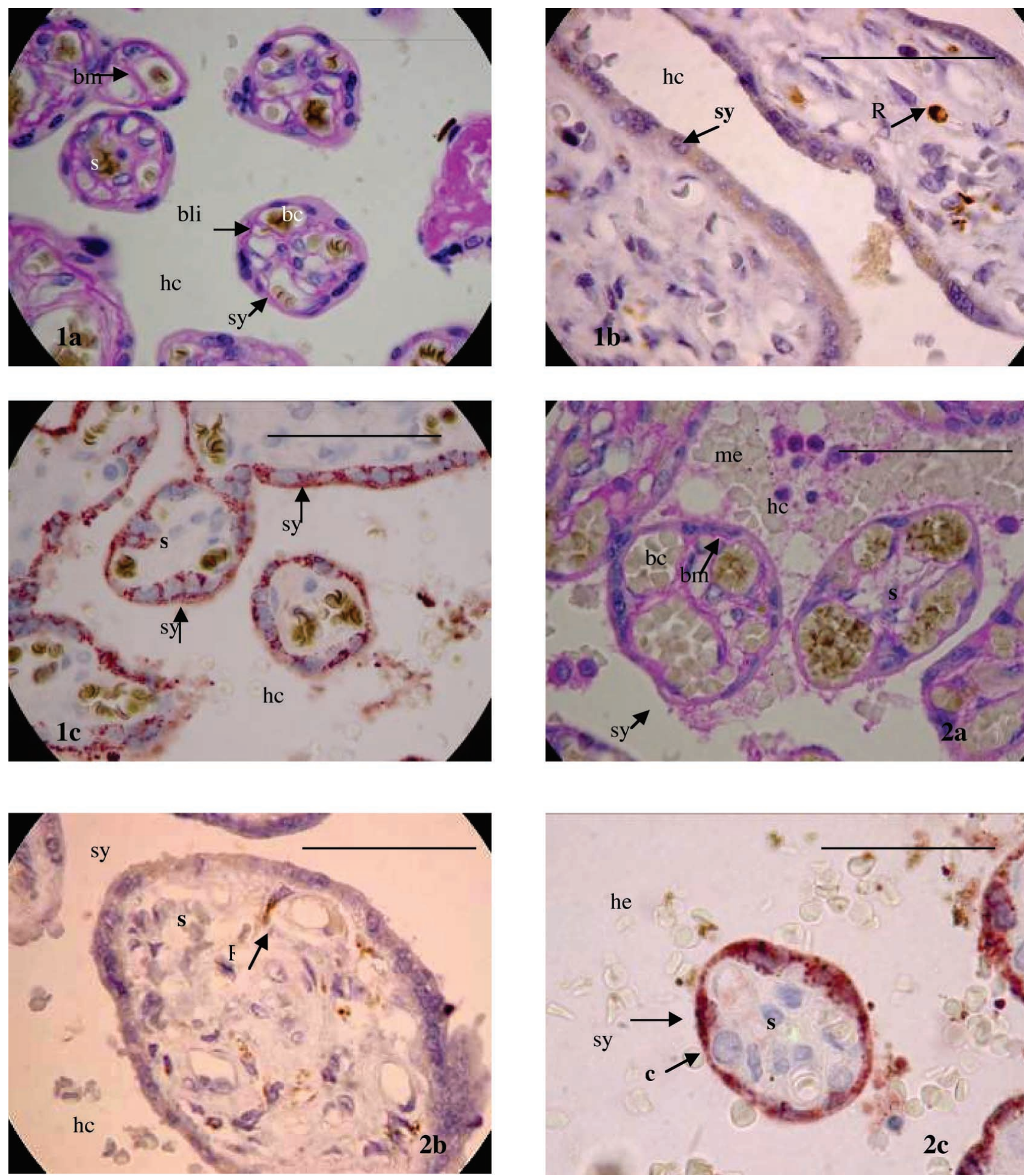

Fig. 1a. The placental free-chorionic villi of AGA newborn. hc: hematic chamber, sy: syncitiotrophoblast, bc: blood capily, e: chorial stromal villi, bm: basal membrane, bli: basal lamina from the trophoblast-stroma interphase. Diastasa-PAS. The bar referes to a $50 \mathrm{um}$ (1000X). Fig. 1b. The intermediate placental chorionic villi of AGA newborn, antibody antireceptor IGF-1. It is observed positive inmunostain in the syncitiotrophoblast and a stroma of one cell. The bar referes to a 50 um (1000X). Fig.1c. The placental free chorionic villi of AGA newborn: Immunohistoquimic technic, antiplacental lactogen. The observed pasitive immunostain in the cytotrophoblast of syncitiotrophoblast and a negative stain in the (s) stroma. Fig. 2a. The terminal free chorionic villi placental membrane of SGA newborn. ch:hematic me: mother erythrocytes, sy: syncitiotrophoblast, bc: blood capillary, s:stroma, bm: basal membrane. Diastasa-Pas (1000X). Fig 2b. The intermediate placental chorionic villi of SGA newborn. Antibody Antireceptor IGF-1. Positive Immunostain browncolor in the cytoplasms of some villi stroma cells, (R) in the syncitiotrophoblast (sc), iv: intermediate villi. The bar referes to a 50 um (1000X). Fig. 2c. The placental chorionic villi of SGA newborn: placental lactogen. Positive immunostain of the cytoplasm of syncitiotrophoblast (sy), instead stroma (s) and cytotrophoblast are negative (c) son negativos. The bar referes to a 50 um (1000X). 
increase of glucose available for its transfer to the fetus (Muñoz \& López-Oliva, 2004). Other researchers (Torry et al., 2004), associated the IUGR, the SGA, the spontaneous miscarriages and the preeclampsia with changes in the vascular development of the placenta. When immunohistochemical observations of placentae from the third term were compared with severe IUGR and normal, a significant decrease in both the villi capillary number per stromal unit and in the capillary area related to the placental stroma was observed. In relation to the lack of formation of blood vessels in IUGR-SGA (Lash et al., 2001), the mechanisms involved in the formation of blood vessels are not yet known but it has been suggested that this could be a defect associated with the production of the more potent angiogenic growth factor VEGF (IGF-1 or 2). However, the results obtained through our analysis showed some differences with this study, such as an increase in the area of the terminal free-villi with no significant decrease in the number of blood capillaries, compared to the control group.
This difference can be explained by the fact that the fetal capillaries in the placenta are not static structures and can adapt to a variety of changes and stress, and also because the peripheral capillaries in the terminal villi are not represented by a highly branched network but instead are composed of elongated capillaries which bend moderately over themselves.

The intention of the score or placental factor proposed in this study is to contribute to the assessment of the placental function, strongly related with neonatal clinical care and the modern methods of perinatal evaluation. In order to use this score, it is required that the placenta be kept after the labour until the conclusion can be reached that there is no relation between neonatal pathology and the placental function. A microscopic study of the placenta should be carried out, backed up by a study protocol and follow-up procedures in each particular case.

PRIETO, R.; MATAMALA, F. \& ROJAS, M. Distribución inmunológica del lactógeno placentario y los receptores IGF-1 en las vellosidades coriónicas libres de los recién nacidos pequeños para la edad gestacional. Int. J. Morphol., 26(4):1029-1033, 2008.

RESUMEN: El objetivo de este estudio fue observar diferencias en la distribución del lactógeno placentario y receptor del factor de crecimiento similar a la insulina, entre placentas de recién nacidos normales para la edad gestacional AEG y pequeños para la edad gestacional PEG. Un total de 12 placentas de recién nacidos AEG y 12 PEG obtenidas de la maternidad del Hospital de Temuco, Chile fueron procesadas con técnicas histológicas H\&E, azul de Alcián y un método de tinción tricrómico. La técnica de inmunoperoxidasa utilizada fue: 1) lactógeno placentario (policlonal, dilución 1:200, NCL-PLP, Novocastra) 2) Factor de crecimiento similar a la insulina (monoclonal, dilución 1:200, NCL-GHR, Novocastra). No se observaron diferencias en la distribución de lactógeno placentario ni factor de crecimiento similar a la insulina entre las placentas provenientes de recién nacidos pequeños para la edad gestacional y adecuados para la edad gestacional

PALABRAS CLAVE: Receptor de IGF-1; Vellosidades coriónicas libres; Recién nacidos; Edad gestacional.

\section{REFERENCES}

Alexander, G. R.; Kogan, M. D.; Himes, J. H.; Mor, J. M. \& Goldenberg, R. Racial differences in birthweight for gestational age and infant mortality in extremely-lowrisk US populations. Paediatr. Perinat. Epidemiol., 13:205-17, 1999.

Belizan, J. M.; Villar, J.; Althabe, F. \& Carroli, G. Retardo del crecimiento fetal. In: Pérez-Sánchez A. Obstetricia. Santiago, Chile, Ediciones Técnicas, 1999. pp. 532-41.

Carlson, B. Embriología Humana y Biología del Desarrollo. $2^{\text {a }}$ edición. Madrid, Elsevier, 1999. pp.110-24.

Dezateux, C.; Lum, S.; Hoo, A. F.; Hawdon, J.; Costeloe, K. \& Stocks, J. Low birth weight for gestation and airway function in infancy: Exploring the fetal origins hypothesis. Thorax, 59:60-6, 2004.
Do Carmo Pinho Franco, M.; Nigro, D.; Fortes, Z. B.; Tostes, R. C. A.; Carvalho, M. H. C. \& Lucas, S. R. R. Intrauterine undernutrition-renal and vascular origin of hypertension. Cardiovasc. Res., 60:228-34, 2003.

Doctor, B. A.; O’riordan, M. A.; Kirchner, L.; Shah, D. \& Hack, M. Perinatal correlates and neonatal outcomes of small for gestational age infants born at term gestation. Am. J. Obstet. Gynecol., 185:652-59, 2001.

Eriksson, J. G.; Forsen, T.; Tuomilehto, J.; Osmond, C. \& Barker, D. J. Early growth and oronary heart disease in later life: Longitudinal study. BMJ, 322:949-53, 2001.

Frisbie, W. P.; Biegler, M.; De Turk, P.; Forbes, D. \& Pullum, S. G. Racial and ethnic differences in determinants of intrauterine growth retardation and other compromised 
birth outcomes. Am. J. Public. Health, 87:1977-83, 1997.

Gluckman, P. D. \& Harding, J. E. Fetal growth retardation: Underlying endocrine mechanism and consequents. Acta Pediatr. Suppl., 422:69-72, 1997.

Handwerger, S. \& Freemark, M. The roles of placental growth hormone and placental lactogen in the regulation of human fetal growth and development. $J$. Pediatric. Endocrino. Matabol., 3:346-56, 2000.

Lash, G.; Macpherson, A.; Liu, D.; Charnock-Jones, S. \& Beker, P. Abnormal fetal growth is not associated with altered chorionic villous expression of vascular endothelial growth factor Mrna. Mol. Hum. Reprod., 7(11):1093-8, 2001.

Leger, J. ; Levy-Marchal, C. ; Bloch, J. ; Pinet, A. ; Chevenne, D. \& Porquet, D. Reduced final height and indications for insulin resistance in 20 years old born small for gestational age: Regional cohort study. BMJ, 315:341-7, 1997.

Muñoz, E. \& López-Oliva, M. E. Sistema GH/Prolactina y crecimiento prenatal. Ann. R. Acad. Farm., 70:4171, 2004.

Newburn-Cook, C. V.; White, D.; Svenson, L. W.; Demianczuk, N. N.; Bott, N. \& Edwards, J. Where and to what extent is prevention of low birth weight possible?. West. J. Nurs. Res., 24:887-904, 2002.

Oren, A.; Vos, L. E.; Uiterwaal, C. S. P. M.; Gorissen, W. H. M.; Grobbee, D. E. \& Bots, M. L. Birth weight and carotid intima-media thickness: New perspectives from the atherosclerosis risk in young adults (ARYA) study. Eur. J. Epidemiol., 18:715-27, 2003.

Sadler, T. W. Langman, Embriología médica con orientación clínica. $9^{\mathrm{a}}$ Ed. Madrid, España, Editorial Médica Panamericana, 2004. pp.123-45.

Strauss, R. S. \& Dietz, W. H. Growth and development of term children born with low birth weight: Effects of genetic and environmental factors. J. Pediatr., 133:6772, 1998 .

Visscher, W. A.; Feder, M.; Burns, A. M.; Brady, T. M. \& Bray, R. M. The impact of smoking and other substance use by urban women on the birthweight of their infants. Subst. Use Misuse., 38:1063-93, 2003.
Vogt, C. I.; Austgulen, R.; Chedwick, L.; Romundstad, P.; Vatten, L. \& Craven, C. Maternal Smoking, intrauterine Growth Restriction, and Placental Apoptosis. Pediatr. Dev. Pathol., 7:433-42, 2004.

Torry, D. S.; Hinrichs, M. \& Torry, R. J. Determinants of Placental Vascularity. AJRI, 51:257-68. 2004.

\author{
Correspondence to: \\ Prof. Ruth Prieto \\ Facultad de Medicina \\ Universidad de La Frontera \\ Casilla 54-D \\ Temuco - CHILE \\ Email: rprieto@ufro.cl
}

Received: 29-03-2008

Accepted: 12-10-2008 
